\title{
BASIC TRENDS IN RESEARCH OF MEDIA COMMUNICATION PSYCHOLOGY
}

\author{
Lidia V. Matveeva \\ Lomonosov Moscow State University \\ Moscow
}

\begin{abstract}
The present paper reveals basic trends of psychological studies in media communications conducted in Russia, in particular, at Lomonosov MSU. The principal researchers, engaged in the field, are introduced: A.A. Leontiev, N.N. Bogomolova, O.T. Melnikova, L.V. Matveeva. The model of human interaction with media space, suggested by L.V. Matveeva, is considered in detail. The paper presents principal results of investigation, undertaken on the basis of the present model, and focused on personality self-expression within telecommunication, as well as characteristic features of telecommunicator and image regulation of mediated intercourse. There also presented some trends in development of media psychology in present day research: a study of reception and recognition of emotions in media communication; the problem of informational-psychological security of spectator; the image of Russia offered by mass media.

Keywords: globalization of media (informational) space; psychology of media communications; inter-personal and mediated intercourse; TV and advertisement communication; a psychological model of interaction of spectator with media space, developed by L.V. Matveeva (the model of "three Russian dolls"); reception of emotions in media communication; the image of Russia offered by mass media; personality self-expression in telecommunication; personality features of communicator; image regulation of mediated intercourse.
\end{abstract}

I. Globalization of informational space and technical innovations, employed in mass media, all this has turned TV and Internet into the most powerful factor, that may affect the world view of an individual as well as collective subjects. Mass media today would remind of a formidable ethno-cultural crossroads, on which the construction of a "Babylonian tower of information" is being endeavoured.

The main purpose of psychology research in the field of media communication, we suggest, comes to scientific consideration of the character assumed by interaction of diverse cultures, provided by mass media. 
To begin with, we would suggest to mark out three dominant traits that specify our existence in the informational 'global village' described by McLuhan:

1) Hectic development of media communications generated the phenomenon of deficiency of useful information against the abundance of information noise, which makes it exceedingly difficult to distinguish between essential and minor matters.

2) Wide dissemination of multimedia means of communication has transformed all spheres of social life into a kind of performance, being directed in its contents as well as in time and space. This initiated yet another dimension in human 'Weltanschauung', the one we call performation. It finds expression in blending of play and practical activity, which Johan Huizinga describes as a universal property of modern culture, manifested through the category of puerility (childishness). Huizinga marks the phenomenon in one's thirst for commonplace entertainment, a demand for sensation and extravaganza, a need to adjust one's behaviour to adolescence rather than mature age (Huizinga, 1992). This makes TV news resemble a show, while the real life provides a spectacle, to take Real TV - show as an example.

3) As mediated modes of interaction between people have come to prevail, visual communication, visual codes and images have usurped priority in informational communication. It has inevitably effected the image of a political leader, whose success now mainly depends on how attractive he may look on camera. A showman has emerged as a new type of hero, and a TV-star has provided a new type of celebrity. The notion of charisma is being transformed into the notion of image, as beauty comes to mean expressiveness.

Integration of media space leads to compression of data flow, and a rich profusion of foreign cultural products. This makes the study of peculiarities of cross-cultural perception of mass media products timely and urgent.

II. The subject matter of psychological research of mass media has been established at the department since its foundation in 1966. The studies were undertaken in the framework of the special course "Psycholinguistics and the Psychology of Media communications" under the supervision of A.A. Leontiev, the son of the founder of our department, an outstanding philologist and psychologist of the University. 
Leontiev suggested the basic parameters of communication processes: objective of communication, psychological dynamics of communication, semiotic specialization, and socially mediated character of communication. The latter is described as social distance that separates the communicator and the recipient of communication, it is measured in the number of stages, through which the message passes undistorted. The stages may assume various functions to attend to the message: editing, controlling, technical, distributing, etc.

Leontiev distinguishes between the notions of intercourse (Mitteilung) and communication: "in most cases communication is generally described as a message (Mitteilung), rather than proper intercourse (Verkehr)." Thus, communication, from his point of view, "comes to a less extent as the process of external interaction of single individuals, but as a mode of internal organization and internal evolution of a society as a whole, being the only process, which makes possible further development of the society" (Leontiev, 1975).

In 1972 the sub-department of social psychology was founded, there the social-psychological sector of mass media studies was investigated under the supervision of N.N. Bogomolova. Principle distinctions be-

Table 1

\begin{tabular}{|l|l|}
\hline Media communication intercourse & Interpersonal communication \\
\hline $\begin{array}{l}\text { Mediation of communication through } \\
\text { technological means }\end{array}$ & Absence of mediation \\
\hline $\begin{array}{l}\text { Intercourse between large social } \\
\text { groups }\end{array}$ & $\begin{array}{l}\text { Intercourse mostly between single } \\
\text { individuals }\end{array}$ \\
\hline Pronounced social objective & Both social and individual objective \\
\hline Orderly institutional character & Mainly spontaneous character \\
\hline $\begin{array}{l}\text { Absence of direct feedback between } \\
\text { communicator and audience }\end{array}$ & $\begin{array}{l}\text { Established feedback between interlocu- } \\
\text { tors }\end{array}$ \\
\hline $\begin{array}{l}\text { Maintenance of moral-ethic norms of } \\
\text { communication }\end{array}$ & Less formal attitude \\
\hline "Collective" character of communicator & "Individual" character of communication \\
\hline $\begin{array}{l}\text { Mass, anonymous, uncoordinated } \\
\text { audience }\end{array}$ & Recipient - a single individual \\
\hline $\begin{array}{l}\text { Unidirectional information and fixa- } \\
\text { tion of parts in communication }\end{array}$ & $\begin{array}{l}\text { Alternating change of direction and parts } \\
\text { in communication }\end{array}$ \\
\hline $\begin{array}{l}\text { Domination of the two-level character } \\
\text { of message perception }\end{array}$ & $\begin{array}{l}\text { Domination of indirect message } \\
\text { perception }\end{array}$ \\
\hline
\end{tabular}


tween mediated and interpersonal communication are marked in her study "Media communication and intercourse" (Table 1).

Peculiarities arranged in the table hardly ever occur in practice in their pure form. There are a number of transitional types between the two extremes of mass media and interpersonal communication. A telephone conversation, for instance, though mediated by a technical device, is still an act of interpersonal communication.

O.T. Melnikova, one of her pupils, conducted a study of peculiarities inherent in youth audience, and singled out different types of aims, interests and values among different groups of young people.

III. Since 1983 by chancellor's order, an inter-department laboratory of "The Psychology of Media communication" has been functioning; nowadays its head is L.V. Matveeva, and T.Ya. Anikeeva, Yu.V. Mochalova, E.E. Petrakova are among the most active research workers.

The group has been engaged in research of the phenomena of TV and advertisement communication in cooperation with Gosteleradio, as well as some leading TV and advertisement holding companies. Accumulated scientific data, and practical evidence, has been suggested for educational purposes on the departments of psychology and journalism of MSU, its practical implication was shaped into recommendations for TV and advertisement personnel. To complete the list, a number of monographs have been issued, one of which was of a summarizing character - Psihologiâ televizionnoj kommunikacii [The Psychology of TV communication] (Matveeva, Anikeeva, \& Mochalova, 2000).

We may assert that interpenetration of latest media technologies, modern psycho-technologies (NLP, GSR, memetics, etc.), and advanced techniques of electronic editing clears the way for essentially new opportunities, which can be employed by mass media to affect both individual and collective consciousness, and to manipulate people on the level of decision making, when they are free to choose. The latest scientific theories of framing (Entman, Gitlin, Friedland, at al.) and construction of social reality (McQuail, Lippmann), in fact, produce recommendations for manipulation with visual representations and verbal constructs to create a virtual reality, which is not controlled by a human, and which may put a serious strain on his psyche.

Modern informational technologies, equipped with latest achievements in psychology, physiology and medicine make it possible to exert 
influence on a human being. All this requires complex study and consideration, involving different fields of scientific research.

IV. A fifteen-year line of investigation, conducted by the group, has culminated in a theoretical model, describing psychological aspects of human interaction within informational space, created by mass media. The group "Psychology of media communication" have analyzed psychological specificity of mediated intercourse. They may be summed up as follows:

1. First and foremost, partners, simultaneously entering communication, increase in number. In case of mediation, the partner in communication is represented by a media holding corporation, which in itself is a highly efficient system staffed by organized personnel, and controlled by the state. On the one side of it there is legislation on media communication, which exercises the state control over communication, financial interests of investors, advertisers and owners of mass media, as well as a social client of a certain media product. On the other side, there comes the management of a media holding company, a creative team and servicing, which create the informational flow, as well as outward and inward sources of information. Recipient or 'passive' partner in mediated intercourse is represented by aggregation of individuals whose integral world pattern reveals all levels of self-identification: an individual as the bearer of a self-image, an individual as the bearer of group norms and values, an individual as the bearer of mentality (social mind). The message comes as a product of combined efforts of people with various specializations in administration and servicing, and the use of technical equipment is strictly hierarchical, similar to hardware, with mobilization of high technology, though the creative team works in the climate similar to that of a party. Contrary to all this, recipient enters media communication as an individual, or aggregation of single individuals.

2. In the event of mediated intercourse the role of image regulation is strengthened. Thus, communicator has to create the message in accordance with the idea of a target group as a partner in communication. For all that, the act of communication presumably proceeds in a quasi-reality, where the self-image, the image of the creator, the image of the spectator, and the image of an ideal communicative message come to interact. Recipient, in his tern, plunged in the atmosphere of remote communication, develops an image of communicator as a partner, acting on the premise of his self-image and the desirable image of the communicative 
message, but taking as a basis the real message of communication. Major peculiarity of such communicative interaction is indispensable distance in time and space between the partners in communication, hence their interaction is translated into a certain symbolic reality.

3. Communicative message comes as the result of efficient work of people with different specializations, they act in the interest of precise social groups or a state system. In this connection the factors, regulating the message character, the form particulars, the choice of verbal codes and imagery used for message creation as well as semantic accents, come to multiply. We marked out seven factors in our structural model of a mediated act of communication, the factors which would affect a communication message:

- Personality (individual) factor. The influence of personal values, goals, ethic norms, and individual features of creative workers of a mass media company over dynamic traits of the communication message (CM).

- The factor of social parts. It implies that social parts, professional terms and personality dispositions within the company staff would affect the language and semantic patterns of the CM.

- The factor of company management. Company objectives, style of management, and professional level would affect strategic policy of the information channel.

- Status factor of a mass media corporation. The level of development of hierarchy in management of creative and technical processes engaged in message creation, and, as a result, a certain status of the corporation among other mass media companies, would affect the policy of the information channel.

- Financial factor. Interests of advertisers, investors and owners may also affect the informational policy of the corporation. They exert indirect influence upon the technical level of information flow, as well as the very image of mass media corporation.

- The factor of the state or public control over the activity of mass media companies. It is established through mass media legislation and affects the semantic level of message and freedom of speech.

- An ideological factor (the context of CM). It reveals the influence of dominant ideology on message contents.

4. Dramatic enhancement of one of the partners through the use of informational technologies leads to intensification of interaction on different levels. 
In 2000 L.V. Matveeva suggested a model of the three-level interaction of individual and collective consciousness in media space, and called it the model of "three Russian dolls" (see Fig. 1).

The structure of communication processes in mass media, we believe, may be shaped into a three-level system of interaction of individual

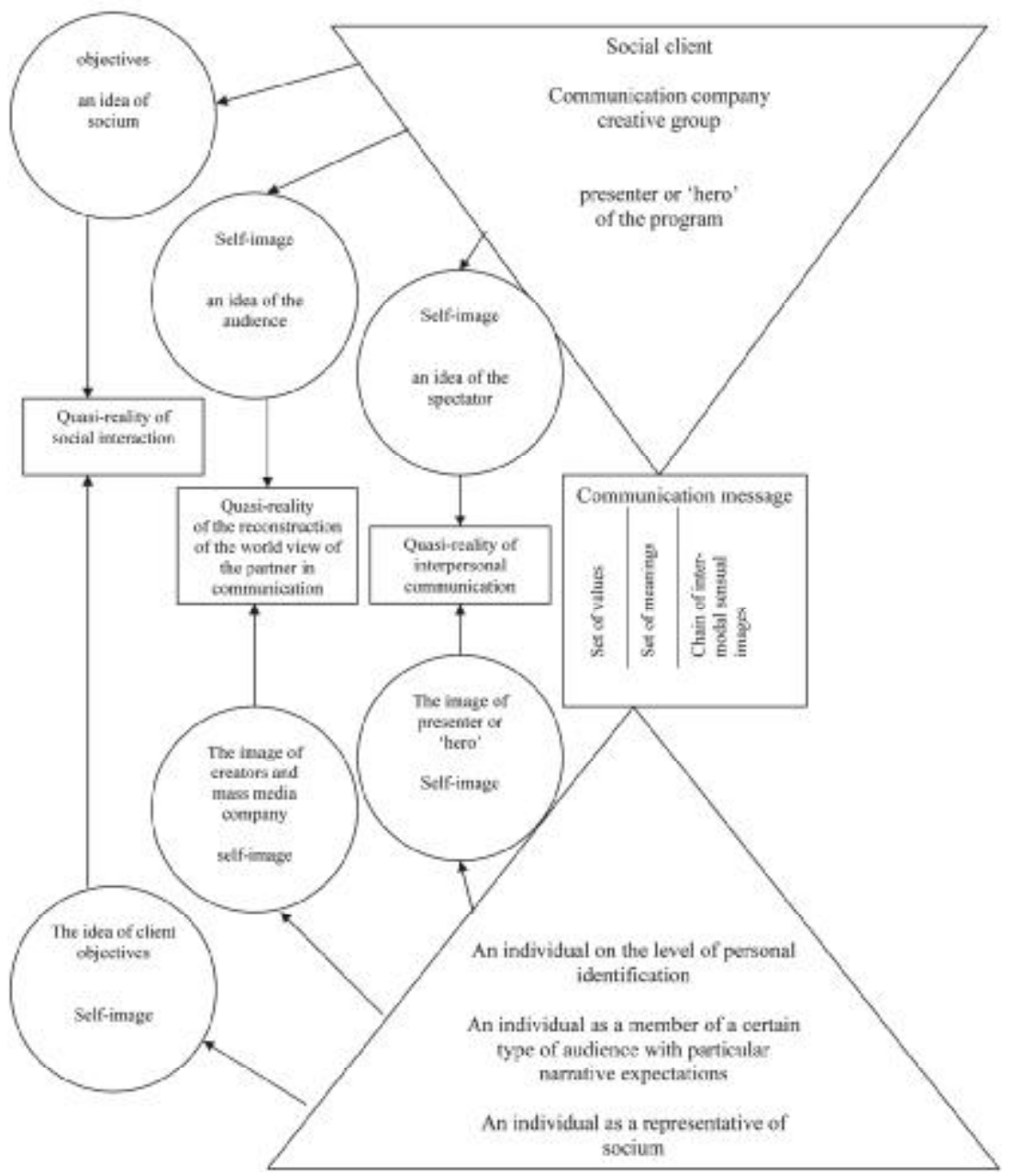

Figure 1. The model of mediated communicative interaction in mass media 
and collective consciousness, in a way similar to Russian dolls put one into another (see Fig. 1). Each of them obviously consists of two parts. Modern conception of the structure of consciousness (Leontiev, 1977; Petrenko, 1988; Bratus, 1994; Asmolov, 1996; Smirnov, 1981) marks out three hierarchical levels.

On the first level, which we may call over-conscious, or the level of mentality, there communicate:

a) a social client of communicative interaction, which keeps his own views of the spectator as a partner in communication (in our case, it is the climate of ideas regarding a particular problem), of the way communication should affect his partner (the objective of communication), and mass media corporation, which brings about the influence (special features of television as public institution aimed at creation of media content);

b) community of spectators, which comes as the collective partner in communication, demonstrating an objective need for a particular sort of information, which many be drawn from their interaction with television (thus television is regarded as the source of information); the audience is regarded to be susceptible to change, as it is meant, in the process of communication (gaining communicative experience, in particular).

This level of interaction (i.e. the level of quasi-reality of social interaction) provides formulation of the basic trends, along which the so called construction of social reality will be furnished on the following stages. It also sets a semantic structure of communication. Cultural and social "frames" are selected for data identification and classification (thus, Entman (1993) suggests that to establish a framing would mean to pick up certain aspects of perceptible reality and to emphasize them in the message, so to provide a specific definition to the problem, its interpretation, moral ingredient and / or recommendations for conduct). This level of interaction is traditionally studied by sociologies, political and culture scientists, and journalists.

On the second level interaction is provided in quasi-reality of the reconstruction of a world view shared by the partner in communication, at this stage there comes the interaction of:

a) a creative team of the mass media corporation, with the group selfimage, the idea of a target audience, intentions, group attitudes, and an ideal image of the communication message, which would 
encapsulate a set of meanings, semantic patterns, and the chain of inter-modal sensual images. This level involves the process of re-formulation of the objective, introduced by a social client into the wording of interaction channel, the process of communication within a particular creative group, set to work over the program, specifying an image or an individual psychological portrait of the target spectator, a set of means and forms that will shape the message, and a prognosis of the effect of interaction;

b) the audience may be regarded on this level from the point of view of social-psychological factors, which may interfere with the message perception. These are: group norms, value orientations, professional and demographic features of the audience, the image of collective communicator (message creators) and their intentions for communication, trust / distrust experienced towards the partner in communication.

The third level, within quasi-reality of inter-personal communication, brings to interact, the following:

a) a communicator, from the point of view of personal characteristics, particular self-concepts and self-actualization in communication, cognitive-communicative style of action, peculiarities of communication repertoire, in his interaction with heroes or participants of the program, the image of CM;

b) TV audience, from the point of view of their individual characteristics of perception and processes of recognition of the objectives and program content, the type of the 'contact' with heroes of the program, attitudes to the creators of the program, and a preconceived image of CM.

In terms of functioning, these levels are separated in time, they appear in psychological analysis in two different forms. First and foremost, it is the process of preparation of TV message as a certain milieu of communication with the spectator; another form is represented by the process of message perception by the audience through interaction with this milieu. The former means realization of the communication set, the latter would imply its experience, consumption and adoption. The psychological content proper, as A.A. Leontiev suggests (1975, p. 69), for this process appear to be "the direction of change in the semantic field of recipient" through interaction of subjective experience of communicator and recipient. 
TV communication on the level of message creation is shaped by the following specificity:

a) the collective character of creativity in program development. Spectator is being addressed by a collective partner in communication, yet the program director would come as a group leader, thus, the message character is shaped by his personal idea of the message objective and a presumptive image of the spectator;

b) wide publicity of processes of interaction between creators and heroes of the program. Even if no one is admitted apart from the film crew during the process of filming, the image of imaginative multi-personality spectator still enters the interaction;

c) individual and personality features of the participants are converted into means to transmit the information, by which substantial aspects of the program are to be interpreted;

d) the character of communication between the director and participants of the program, as well as their attitude to message content shape a communicative aspect of the message. They surface with the choice of means and forms of interaction within the structure of telecommunication.

Specificity of telecommunication on the level of perception, comprehension, and interpretation of CM by the audience includes the following:

a) the functioning of motivational-demanding sphere of an individual, which comes as a member of the society as regards telecommunication;

b) peculiarities typical for perceptive, cognitive and mnemic processes as regards mass media discourse;

c) a high level of mediation in human communication behaviour in TV sphere;

d)characteristics of image representation of the partner in communication (communicator) and CM in individual consciousness.

The most complicated matter in arrangement of the effective, i.e. unbroken communication is to create an efficient feedback between the partners. It appears, at the same time, to be the most topical problem of psychological studies.

$\mathrm{V}$. The suggested model yielded most urgent problems of further investigation. 
A particularly active position of the creator and initiator of communication (the journalist), is established by the fact that he will arrange the environment of communication, with the assigned place and part for his future partner in communication; he will provide the means of regulation of the interaction (a set of audio-visual tools to fix the constant attention on the screen, as well as emotional contact, individual involvement of the spectator), he will contrive the most effective ways of self-expression, his personality view. We undertook the investigation of personality features of creative TV staff as regards creation of CM. The following data have been achieved in dissertation paper of T.Ya. Anikeeva (2006).

The structure of personality features of telecommunicator is formed by three basic foundations:

1) positive / negative set of personality self-consciousness;

2) creative self-fulfillment of personality, being on the 'flow' (modus of 'being' / 'possession');

3) social activity, responsibility / social passivity, irresponsibility.

Personality features of TV hosts lie at the basis of their self-presentation on the air and affect the differentiated perception of their images by spectators. This asserts the fact, that audience would take the man on the screen as a partner of his full value, and the experienced contact would come in its content rather close to inter-personal communication.

Professional success and creative self-fulfillment of communicator's personality is furnished by harmonious coordination of the qualities peculiar to actors, artists, or musicians (such qualities as emotional refinement, inclination for artistic activity, imaginative thinking and intuition) with the qualities peculiar to administrators, managers and directors (these are: sociability, ego strength - emotional stability, high level of behaviour self-control, and willingness to assume responsibility for the group-work).

Another line of investigation comes to focus on Popularity of telecommunicator approaching it as the phenomenon of mass consciousness. This is determined by the very success of creative self-expression of the TV actor through the means adequate for his audience. Thus, it is important 1) to study the phenomenon of popularity as the model of an 'ideal' partner in telecommunication, and 2) to examine characteristic features of communication objectives of the real audience, since communication is arranged and carried on with a screen image, created by journalist. 
Within the framework of dissertation paper of Yu.V. Mochalova (2005) there were distinguished principle factors of TV popularity, these are: personal charm or attraction of the TV person; ethical orientation of personality; traits or habits of temperament, ego strength; optimism. In further research these categories were verified and complemented by image characteristics of the phenomenon, cognitive and communicative features, as well as peculiarities of world outlook.

Yet another line of investigation concerns communicative objectives and informational preferences of TV creators and audience. Telecommunication brings intensification about the whole process of discourse with the strongest accent on the individual and his / her internal world. On the one hand, we take a look at the man from the close shot, thus television comes as a 'microscope' for a person; on the other, cognitive and emotional 'space' of the spectator grows wide, as well as his / her repertoire of behaviour.

In connection with all this it seems necessary:

- to investigate the mechanism of CM creation;

- to describe the psychological portrait of TV audience as a collective subject of communication;

- to compare the images of CM, conceived by creator and spectator, and mark out the principal traits of a TV program, which provide effectiveness of communication contact.

As it was demonstrated by E.E. Petrakova in her dissertation paper (2007), it is particularly characteristic of present day Russian journalists to contrast 'we - they', 'friend-and-foe' in their relations with audience. We can trace dissent among subjects of TV communication in their informational preferences: spectators would rather have news programs of far more serious kind, than creators will admit.

VI. Present day research of electronic media psychology are developed along the following trends:

1. Human perception of emotional states in media communication. There was conducted the experimental study of human ability for perception and recognition of emotions suggested by the computer. The main purpose of the study was to analyze peculiarities in recognition and identification of human emotions by the audience.

There are several channels through which human emotions in communication are exhibited. In case of mediated intercourse, when a screen 
version of emotional experience is introduced, the main non-verbal channels appear to be human mimics, postures and gestures. The context of behaviour is set by objective situation of communication, the 'semantics of actions' of communicator.

Our study aimed to investigate the process of perception and identification of personality emotional experience, exhibited on the monitor. As a stimulation material we used recordings of TV programs, which heroes presumably experienced one of the emotional states (according to C. Izard and G. Schlosberg classification). In this we held the view, that medical methods may not be quite adequate in identification of personality emotional state (these are the so called objective methods, employed for registration of emotions: physiological, psychological, and electric physiological, such as cardiogram, plethysmogram, EEG). Medical methods will suffice only for identification of 'undisturbed,' isolated emotional state. Our research offers complex methodology for identification of emotional states exhibited in TV recordings. This involves, on the one hand, a device of the set of colour codes, assigned to perception of a personality state on screen by eight testing cards of M. Lüscher, and method of scoring and verbal associations, introduced by D. Price, G. Barrel, and C. Izard, on the other. This examination, as distinct from physiological methods of registration of emotional states, makes it possible to get a simultaneous cross-section of the whole palette of the present emotional states experienced by an individual.

Selection of video fragments and slides, used for demonstration of the nine emotional states (tranquility, aversion, surprise, interest, fear, embarrassment, grief, aggression, and elation) was conducted by expert psychologists. Stimulating material was arranged in the following way: a two-minute TV story, representing a close shot of a person in a certain emotional sate, was cut into 7 pieces; experts would score each slide within the nine-grade scale to identify eight basic emotions (elation, hostility, surprise, rage, embarrassment, tranquility, fear, grief). Story assessment was generally conducted upon 30 parameters of a 5-grade scale. There were all in all nine stories. Thirty-two experts took part in the examination, they were specially selected to satisfy the following demands: sex, age, extraversion-introversion. Participants were divided into 6 groups: males up to 35 years of age ( 8 people), males after 35 ( 8 people), females up to 35 years of age ( 8 people), females after 35 ( 8 people), extraverts (10 people), introverts (10 people). 
Principal results were as follows:

1) The process of perception and identification of emotional experiences represented on the screen has its specificity to compare with the perception in direct interpersonal communication, it reveals intensification of communicative component in emotions, additionally assigned by recipients to characters of video stories. That is, spectator enters interpersonal communication with a TV character, expecting that his emotions will address him personally as a partner in communication.

2) The process of perception is complex in its nature and reveals a certain dramatic concept of recognition, differentiation and assessment of inter-correlation of basic emotions in a certain image of a person on the screen, involved in a certain emotional state. First three slides would actualize a wide range of emotional states in expert spectator. The next two or three slides would reveal a complex of basic emotions, as well as a complex of background emotions, and the set of emotions, characteristic for one of the expert groups.

3) The following differential distinctions were marked out in emotional perception within testing groups: the male group would rather quickly and unambiguously identify a basic emotion, and as a rule, would not assign additional emotions to story characters; the female group would distinguish a greater number of components in a suggested emotional experience, which means that they possess a more complex image of emotional set.

4) Extraverts and introverts differ in their emotional perception. In the group of extraverts additional emotions exhibit substantial variety and appear to be directed outwards, which may be accounted for by particular sensitivity of extraverts to the emotions which accompany intercourse, as well as to their partner in communication. In other words, they demonstrate the heightened 'inner background activity' towards communication signals (set of another person as 'significant other'). In the group of introverts differentiation of the basic emotional experience in perception of emotional set is rather shifted in time concerning the initial phase of perception, that is, reveals a 'retarded' character.

2. We conducted research of data-psychological security in TV and advertising communications.

Within the framework of studies we undertook a data examination of psychological and philological aspects of information security. To address the problem of data-psychological security we should, from the 
outset, define and shape the concept of psychological borderline of data security. The fact that the borderline is set in mental space of subjective reality, where the norms appear to be of mostly conventional character or taboo, as a ban applied to certain behaviour of some individuals or groups in a society, makes our task exceedingly difficult. Hence, the borders marked for data security should in their contents assume psychological and ethic character, while in form they should be developed as the norms of legislation. Thus, in particular, the patterns of emotional expression, the mode of thinking, the character of volitional control of behaviour, the features of verbal and non-verbal communication are vulnerable enough for informational aggression of another culture or a different world view. All stated before will demand interdisciplinary approach in the working out of data security in TV and advertisement communication.

We have marked out a number of categories of complex content analysis on the philological and psychological levels. The philological level (journalism) reveals the following essential characteristics of advertisement study: reality of the situation (as it may or may not happen in real life); a degree of story development, further detalisation of the plot; the use of adjectives and adverbs somewhat overstating virtues of an article or service; the hints of humour; the introduction of fantastic elements or erotic motives. Psychological criteria are as follows: moralethical; of emotional comfort; of cognitive complexity and clarity; of the level of disharmony of the image-bearing vocabulary; peculiarities of the pattern of humour culture; a degree of vigour or aggressiveness. We have analyzed the processes of reflection of TV workers as the basis for providing data security in mass media.

There has been undertaken an expert content analysis of the following data products: advertisement products meant for children and adolescents during the day-time (from 9-00 till 21-00), children's programs; TV project Za Steklom [Behind the Glass]. We have marked out dangerous and secure media products as regards their plausible impact on the human psyche. The concept of MTV channel was analyzed as regards data security. We have also revealed the structure and dominant trends of children's broadcasting on Russian TV.

There have also been made a laboratory experiment to expose the factors of data security for children, adolescents and youth. We used advertising stories awarded on the latest international festivals "Cannes 
Lions" to examine semantics for danger / security categories in media space; to reveal categorial structure in perceiving of advertising messages; to mark out dominating tendencies in development of advertisement creativity. The first series of experiments have been conducted to expose peculiarities of perception of emotionally significant images of advertisement in media communications. Outward means of advertisement were examined as the source of overstimulation of human psyche. Personality features of telecommunicator were also investigated as one of the components of data security factor in media communication. The phenomenon of "Pokémon," the favourite children's TV hero, was also subjected to psychological analysis.

3. We investigated the categorial structure in perception of the image of Russia for the people of different regions of the country, and subjects of Belarus (see Fig. 2, 3, 4). Comparative analysis of categorial structure of presentation of the image of Russia in mentality of people in both countries leads to the following conclusions:

During two years (2007-2009) the research group of the laboratory of "Psychology of media communication" of Psychology department of Lomonosov MSU mass media image of Russia was investigated in mentality of Russian people and the people of the neigbouring country Belarus. The methods of interviewing, questionnaire, and semantic differentiation were employed. The image of Russia in people's mentality was examined in three aspects: Russia - country, Russia - state and Russia of the future. Achieved results revealed the following basic categories, shaping the image of Russia in mass media and mentality of various groups of Russians: rich - poor; strong - weak; bosom - estrange; generous - stingy; educated - ignorant; spiritual - materialistic; warm - cold; eastern - western; democratic - totalitarian; comfortable - miserable; patriotic - cosmopolitan; sly - openhearted; communal - individualistic; peaceful - belligerent. Thus, in Russian mentality the country, first and foremost, is represented as a state power, people would rather emphasize its spiritual potential, ethnocultural identity, social lifestyle, and character of inward and outward communication.

Most people of Russia are prone to think that the image offered by mass media is poorer, weaker, colder, more estrange, ignorant, dependant and pro-Western than that of the real Russia-country and Russiastate. The image of future Russia is postulated by its people as flourishing, strong, bosom, eastern, warm, independent, rich and educated. 


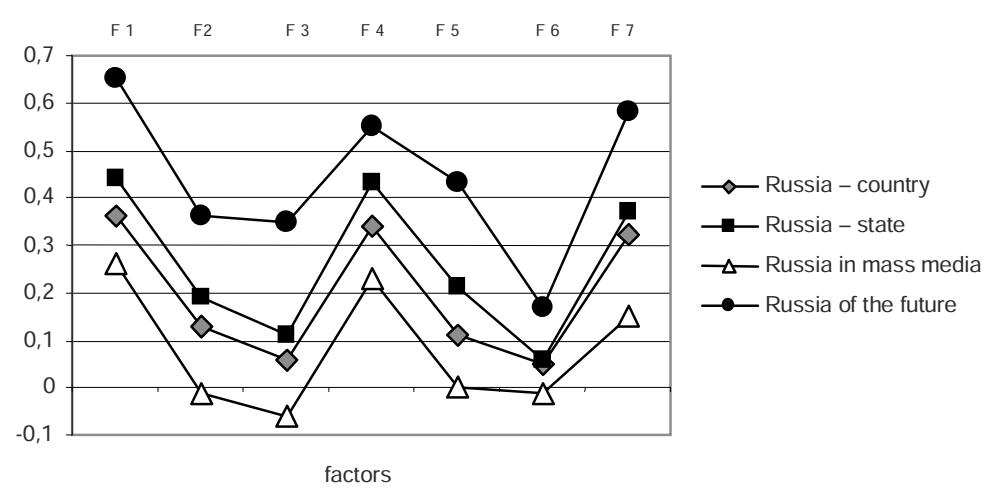

Figure 2. The image of Russia in categorical space of respondents perception in Belarus

Categorial structure of the image in mentality of people of Belarus suggests such categories as strong - weak, belligerent - peaceful, dirty clean, beautiful - ugly, chaste - lecherous, bosom - estrange, stingy generous, communal - egoistic, totalitarian - democratic. It is peculiar that the image of Russia as country and state, the image offered by mass media, the image of future Russia and the image of the USA are encapsulated in one cluster, while the image of united Europe, Kazakhstan, Turkey, China, Israel and Japan form another cluster. The image of the Ukraine does not come into either cluster.

Those living in Khanty-Mansiysk believe Russia to be one of the most successful countries along with Japan and China. On the contrary, citizens of Perm would place it among outsiders, such as Kazakhstan and the Ukraine. Journalists in Moscow would assign to the image of Russia such qualities as: bosom, strong, cold, individualistic and patriotic within reasonable limits. Among journalists the image of Russia is very close to the image of United Europe.

The image of Russia offered by mass media in collective consciousness of Moscow journalists is identical to the image of Russia-country, while the image of Russia-state is estimated considerably lower than that of Russia-country. The futuristic image of Russia would resemble the image of a fairy land "Eldorado," that is, it comes as comfortable, bosom, peaceful, strong, warm, communal, and patriotic. 


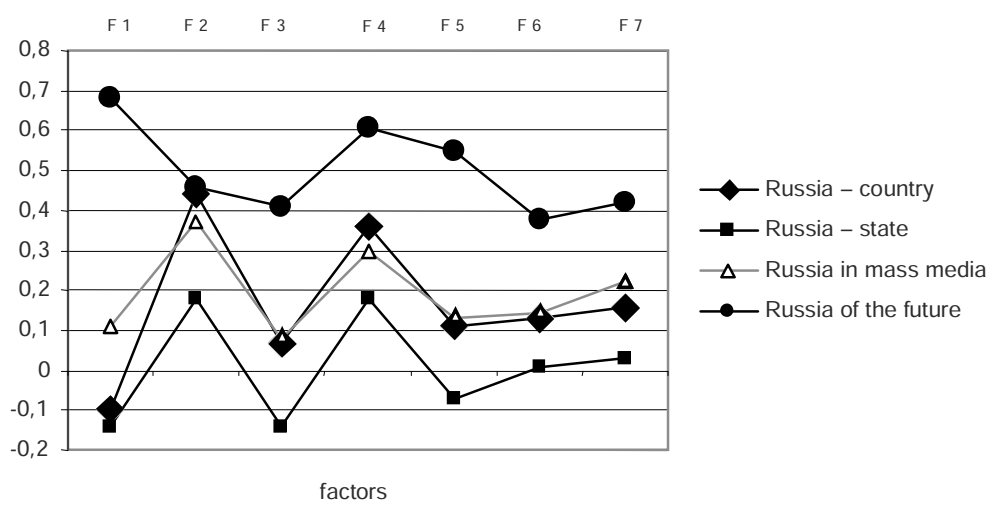

Figure 3. The image of Russia in categorical space of the perception of a group of Moscow journalists

The image of Russia offered by mass media with people in Novosibirsk would be identical to the image of Russia-state, while the image of Russia-country comes close to Russia in future. The same tendency is exhibited by the students in Moscow. The image of Russia offered by mass media and the image of Russia-state would be identical in almost all categories, while the image of Russia-country is closer to futuristic image of Russia. We may ascertain some distancing of people in Siberia and Moscow students from the image of Russia offered by mass media.

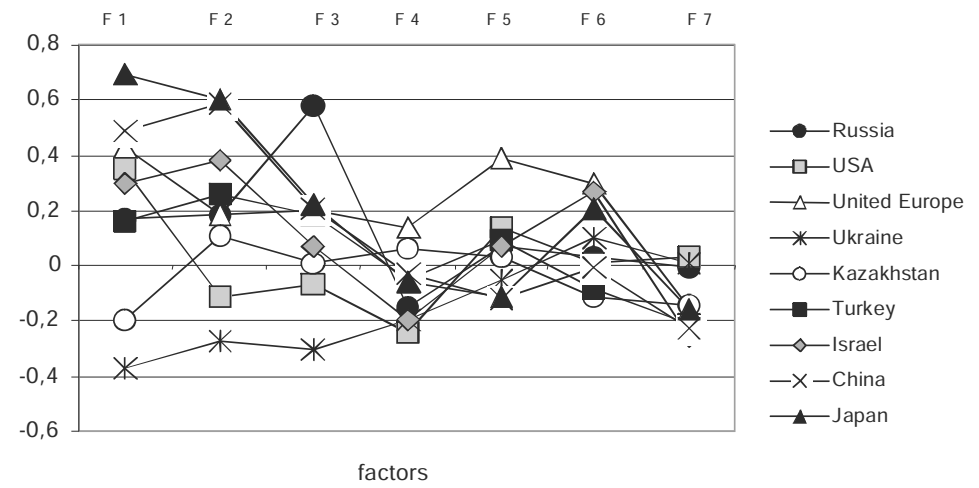

Figure 4. Arrangement of country images in categorical space of perception of respondents in Novosibirsk 
The image of Russia-country and Russia of the future would come as basic identity for people of these regions.

Very peculiar is the fact that futuristic image of Russia with most respondents of various groups would bear a fairy-tale, metaphoric character to embody the image of unattainable ideal, somewhat similar in wording to a childe song - 'a distant faraway. Thus, journalists remain quite positive, that they create an adequate image of Russia-country, while people of Russia believe, that the image of Russia offered by mass media is considerably worse, than the real image of the country. Yet again we face the phenomenon of "broken communication" in a public dialogue between the Creator and the Spectator, in which audience does not recognize itself and the country in the mirror of mass media presentation. The image of Russia as a country and state comes close in people's view to that of the USA, but it is almost identical to the image of Russia offered by mass media. In that way even the people of an allied state, similar to us in mentality, shape their image of Russia on the idea offered by mass media. It appears as if the image of Russia presented in mass media comes very close to the image of the USA.

In conclusion we may state, that the subject matter of mass communication and informational psychology has virtually developed into a separate trend of media psychology, and its scientific results are put to practice, and widely employed in education in the courses on "Psychology of communications," "Psychology of convincing communication," and "Psychology of public discourse."

\section{References}

Anikeeva, T.Y. (2002). Ličnost' telekommunikatora kak faktor informacionnopsihologičeskoj bezopasnosti. In Informacionna â i psihologičeskâ̂ bezopasnost' v SMI (pp. 132-141). Moscow: Aspekt Press.

Asmolov, A.G. (1996). Kul'turno-istoričeskâ̂ psihologiâ i konstruirovanie mirov. Moscow: Institut praktičeskoj psihologii, Voronezh: MODEK.

Bogomolova, N.N. (1988). Massovâa kommunikaciâ i obŝsnie. Moscow.

Bratus, B.S. (1994). Psihologiâ. Nravstvennost'. Kul'tura. Moscow: Rospedagenstvo.

Leontiev, A.A. (1975). Obŝenie kak ob”ekt psihologičeskogo issledovaniâ. In Metodologičeskie problemy social'noj psihologii. Moscow: Nauka. 
Leontiev, A.N. (1977). Deâtel'nost'. Soznanie. Ličnost'. Moscow: Politizdat.

Izard, C. (1980). Emocii čeloveka [Human Emotions]. Moscow.

Dontsov, A.I., Zassoursky, Ya.N., Matveeva, L.V., \& Podolsky, A.I. (Eds.). (2002). Informacionnaâ i psihologičeskaâ bezopasnost' v SMI. Vol. 1: Televizionnye i reklamnye kommunikacii. Moscow: Aspekt Press.

Zassoursky, Ya.N., Zinchenko, Yu.P., Matveeva, L.V., Vartanova, E.L., \& Podolsky, A.I. (Eds.). (2008). Informacionnâa i psihologičeskâa bezopasnost'v SMI. Vol. 2: Fenomen "razorvannoj kommunikacii." Moscow: Aspekt Press.

Matveeva, L.V., Anikeeva, T.Ya., \& Mochalova, Yu.V. (2000). Psihologiâ televizionnoj kommunikacii [The Psychology of TV communication]. Moscow: Učebnometodičeskij kollektor "Psihologiâa"

Matveeva, L.V. (2000). Obŝenie v sfere televideniâ (Candidate of Sciences dissertation). Moscow.

Mochalova, Yu.V. (2002). Ustanovlenie kontakta s auditoriej v televizionnoj kommunikacii. In A.I. Dontsov, Ya.N. Zassoursky, L.V. Matveeva, \& A.I. Podolsky (Eds.), Informacionnầ i psihologičeskaâ bezopasnost' $v$ SMI. Vol. 1. Televizionnye i reklamnye kommunikacii. Moscow: Aspekt Press.

Zinchenko, Yu.P., \& Matveeva, L.V. (Eds.). (2008). Obraz Rossii v strane i za rubežom: gumanitarnoe izmerenie. Moscow.

Petrakova, E.E., \& Matveeva, L.V. (2008). Predstavleniâ avtorov i zritelej drug o druge i o kommunikativnom poslanii v televizionnom obŝenii. In Ya.N. Zassoursky, Yu.P. Zinchenko, L.V. Matveeva, E.L. Vartanova, \& A.I. Podolsky (Eds.), Informacionnaâ i psihologičeskaâ bezopasnost' y SMI. Televizionnye i reklamnye kommunikacii. Vol. 2. Fenomen "razorvannoj kommunikacii." Moscow: Aspekt Press.

Ochirova, A.V., Zinchenko, Yu.P., \& Matveeva, L.V. (Eds.). (2008). Sovremennyj obraz Rossii: perspektivy razvitiâ. Moscow.

Petrenko, V.F. (1988). Psihosemantika soznaniâ. Moscow.

Smirnov, S.D. (1981). Mir obrazov i obraz mira. Vestnik Moskovskogo universiteta. Seriâ 14 "Psihologiâ," 2, 21-29.

Huizinga, J. (1992). Homo Ludens. V teni zavtrašnego dnâ [Homo Ludens. In the Shadow of Tomorrow]. Moscow: Progress.

Matveeva, L.V. (2005). Perception of Publicity Texts in Television Communications. In Perspektiven auf Mediensprache und Medienkommunikation. Amades, Institut fur Deutsche Sprache. Germany.

McLuhan, M. (1995). Essential McLuhan. New York: Basic Books.

Schlosberg, H. (1954). Three Dimension of Emotion. Psychological Review, 61, 81-88. 